\title{
Study on Regulation of Growth and Biosynthesis of Cellulolytic Enzymes from Newly Isolated Aspergillus fumigatus ABK9
}

\author{
ARPAN DAS, TANMAY PAUL, SUMAN KUMAR HALDER, CHIRANJIT MAITY, \\ PRADEEP KUMAR DAS MOHAPATRA, BIKASH RANJAN PATI and KESHAB CHANDRA MONDAL*
}

Department of Microbiology, Vidyasagar University, West Bengal, India

Received 17 April 2012, revised 6 July 2012, accepted 3 September 2012

\author{
Abstract
}

This study was aimed to evaluate the pattern of cellulase biosynthesis from Aspergillus fumigatus ABK9 under submerged fermentation. Production was increased concomitantly with fungal growth up to $72 \mathrm{~h}$ and reached maximum $\left(\mathrm{X}_{\max }-6.72 \mathrm{~g} / \mathrm{l}\right)$ with specific growth rate $\left(\mu_{\text {max }}\right)$ of $0.126 / \mathrm{h}$. Highest specific rate of enzyme production $\left(\mathrm{q}_{\mathrm{p}}\right)$ was found at initial medium $\mathrm{pH}$ of 5.0 and incubation temperature of $30^{\circ} \mathrm{C}$. At the same time, in the presence of 2-deoxy-D-glucose concentration of $0.5 \mathrm{mg} / \mathrm{ml}$, the production of cellulolytic enzymes, $v i z$, carboxymethyl cellulase activity (CMCase), filter paper degrading activity (FPase) and $\beta$-glucosidase activity reached maximum of 132.2, 21.3 and $28.9 \mathrm{U} / \mathrm{ml}$, respectively. Cellulase biosynthesis was induced in respect to higher volumetric production rate $\left(\mathrm{Q}_{\mathrm{p}}\right)$, specific rate of enzymes production $\left(\mathrm{q}_{\mathrm{p}}, \mathrm{U} / \mathrm{g}\right.$ biomass $\left./ \mathrm{h}\right)$ and enzyme/biomass yield $\left(\mathrm{Y}_{\mathrm{E} / \mathrm{X}}\right)$ when grown in carboxymethyl cellulose in comparison to other saccharides as sole carbon source. Induction ratios (IR) of cellulases were between 12.3 and 24.4 in the presence of $1.5 \%(\mathrm{w} / \mathrm{v})$ $\mathrm{CMC}$ in the culture media. The strain was quite resistant to catabolic repression by glucose up to $0.4 \%$ ( $\mathrm{w} / \mathrm{v}$ ). Cellulases production was greatly influenced in the presence of yeast extract and potassium dihydrogen phosphate $\left(\mathrm{KH}_{2} \mathrm{PO}_{4}\right)$ as nitrogen and phosphate sources in the culture media. $\mathrm{C} / \mathrm{N}$ ratio of 10.0 and $\mathrm{C} / \mathrm{P}$ ratio of 4.0 proved to be the best for the production of enzyme cocktail. Along with the high production yield, the crude enzymes showed a promising cellulose hydrolyzing efficiency of rice straw, indicating the enzyme could be beneficial for its large scale industrial exploitation.

Ke y word s: Aspergillus fumigatus, cellulase production, growth regulation, submerged fermentation

\section{Introduction}

Cellulose is a water insoluble un-branched homopolysaccharide consisting of glucose subunits joined together via $\beta$ 1-4 glycosidic linkages (Lederberg, 1992). It was estimated that the photosynthetic process produces about $1.5 \times 10^{11}$ tons of dry material annually with respect to carbon on earth, of which about $50 \%$ is cellulose (Kubicek et al., 1993). Enzymatic hydrolysis of cellulose is of major importance from both natural and engineering aspects. The cellulase hydrolyzed products are now exploited for sustainable production of biofuels, biopolymer and important natural or derivatized chemicals (Rodrigues et al., 2011). Besides, cellulases have enormous industrial applications in the food, agriculture, brewery, textile, detergent, animal feed, pulp and paper industries (Das and Ghosh, 2009; Demain et al., 2005; Yue et al., 2009; Singhania et al., 2010; Ibrahim etal., 2011). Cellulase is an extracellular multienzyme complex that exhibits high activity against crystalline cellulose. To date, more than
20 catalytic subunits of this enzyme have been analyzed, and these subunits collectively show a variety of activities, including endoglucanase, exoglucanase, xylanase, mannanase, chitinase, and lichenase (Zhang and Lynd, 2005). Generally, three major type of enzymes; endo-1,4- $\beta$-glucanase (carboxymethylcellulase, or $\mathrm{Cx}$ cellulase), cellobiohydrolase (exoglucanases, $\mathrm{CBH}$, Avicelase, C1 cellulase or FPase), and $\beta$-glucosidase (cellobiase) act synergistically in the saccharification of cellulose. Degradation of cellulose is started by the random attack of endoglucanases at regions of low crystallinity, which creates free ends for the action of cellobiohydrolases that release cellobiose units from the ends of the chain and finally $\beta$-glucosidases cleave cellobiose to glucose (Yue et al., 2009; Singhania et al., 2010; Ibrahim et al., 2011).

There is a wide group of microbes having the ability to synthesize cellulases, but only some fungal genera, like Trichoderma, Sporotrichum (Phanerochaete), Aspergillus, Fusarium, Humicola and Talaromyces, (Singhania et al., 2010; Ibrahim et al., 2011; Zhang and Lynd,

* Corresponding author:K.C. Mondal, Department of Microbiology, Vidyasagar University, Paschim Midnapore-721102, West Bengal, India; phone: (91) 03222-276554/555 (ext. 477); fax: (91) 03222-275329; e-mail: mondalkc@gmail.com 
2005; Jeng et al., 2011) are commercially used for cellulase production.

Cellulases are inducible microbial enzymes and regulation of their biosynthesis is finely controlled by activation and repression mechanisms (Mach and Zeilinger, 2003). This regulation is an important feature of the physiology of the microorganisms, particularly in the light of the substantial investment of ATP that cellulase synthesis represents. Moreover, this regulation is a central determinant of enzyme synthesis and growth rate and thus is of interest for understanding cellulose utilization in both natural environments and industrial processes. The production of cellulolytic enzymes is generally induced in the presence of cellulosic substrates (Mandels et al., 1962; Sun et al., 2008). Sophorose, a natural disaccharide, was considered to be the most active inducer for Trichoderma cellulase synthesis. Contradictoryly cellobiose, d-cellobiose-1-5-lactone and other oxidized products of cellulose hydrolysis can also act as inducer for cellulase (Vaheri et al., 1979; Lynd et al., 2002). Lactose is another known inducer of cellulase and it is utilized in commercial production of the enzyme owing to economic considerations. Though cellulase is induced by cellulose and its derivatives or by a few low molecular weight carbohydrates, but its formation is repressed by readily metabolized substrates like glucose (Sun et al., 2008), such a repression mechanism for enzyme synthesis is of widespread occurrence in microorganisms and was first referred to as the 'glucose effect' (Epps and Gale, 1942) and later termed 'catabolite repression' (Magasani, 1961).

To express the parameters related to cellulase production and growth of the isolate, different fermentation process kinetics were employed, which are potentially valuable for the improvement of batch process performance. This was largely the result of empirical simplifications offered by the 'unit operations' concept in chemical engineering (Elmer and Gaden, 2000).

2-deoxy-D-glucose (DG), a glucose analogue, has frequently been used to isolate glucose-deregulated mutants (Haq et al., 2001) and is well recognized to regulate the formation of repressible proteins (Lockington et al., 2002) as well as to enhance the expression of inducible enzymes which are used for improved production of cellulases in different organisms (Rajoka et al., 1998).

The objective of the present study was to investigate the kinetics of cell growth and cellulase synthesis from a potent indigenous cellulolytic fungal isolate using different 2-Deoxy-D-glucose concentrations, medium formulations and culture conditions. At the same time, induction and repression pattern cellulase biosynthesis during submerged fermentation have also has been explored. The information obtained from this study may be useful for better understanding of the fermentation process for the improvement of cellulase production.

\section{Experimental}

\section{Materials and Methods}

Microorganism. Cellulolytic fungal strains from different soil, water and plant samples from different provinces of the District of Howrah and Midnapore of West Bengal, India, were initially screened on Mandel agar media [ having the composition of $\mathrm{KH}_{2} \mathrm{PO}_{4}, 2.0$; $\left(\mathrm{NH}_{4}\right)_{2} \mathrm{SO}_{4}, 1.4$; Urea, $0.3 ; \mathrm{MgSO}_{4} \cdot 7 \mathrm{H}_{2} \mathrm{O}, 0.3$; $\mathrm{CaCl}_{2} \cdot 2$ $\mathrm{H}_{2} \mathrm{O}, 0.4 ; \mathrm{FeSO}_{4} \cdot 7 \mathrm{H}_{2} \mathrm{O}, 0.005 ; \mathrm{MnSO}_{4} \cdot \mathrm{H}_{2} \mathrm{O}, 0.0016$; $\mathrm{ZnSO}_{4}, 7 \mathrm{H}_{2} \mathrm{O}, 0.0014 ; \mathrm{CoCl}_{2}, 0.0020$; Carboxymethyl cellulose, 10; and agar $17.5 \mathrm{~g} / \mathrm{l}, \mathrm{pH}-5.0]$. Among 32 primary isolates, based on the index of relative enzyme activity $\left(\mathrm{I}_{\mathrm{CMC}}\right)$, higher yield of cellulolytic enzymes (CMCase, FPase and $\beta$-glucosidase) and higher degradation efficiency of cellulosic substrates, a potent fungal strain $\mathrm{ABK} 9$ was finally selected. Culture was grown on potato dextrose agar slants at $30^{\circ} \mathrm{C}$ and the fully sporulated slant obtained after 5 days of incubation was stored at $4^{\circ} \mathrm{C}$ for further use.

Identification of potent fungal strain. Taxonomic identity and phylogenetic relationship of the potent fungal strain (ABK9) was investigated on the basis of its morphological and $28 \mathrm{~S}$ rRNA profile. In brief, fungal genomic DNA was isolated with the Qiagen DNA extraction Kit (Qiagen Sciences Inc, Germantown, MA) following the manufacturer's instructions. A polymerase chain reaction (PCR) was performed to amplify $\mathrm{D} 2$ region of LSU (Large subunit $28 \mathrm{~S}$ rDNA) gene using DF (5'ACCCGCTGAACTTAAGC3') and DR (3'GGTCCGTGTTTCAAGACGG 5') primers with the help of Taq polymerase (HiMedia, India). The amplified PCR product was purified and sequenced using BDT v3.1 Cycle sequencing kit on ABI 3730xl Genetic Analyzer. The D2 region of LSU gene sequence was blasted and aligned using the CLUSTALW software. Based on maximum identity score, the first ten sequences were selected and a phylogenetic tree was constructed using MEGA 4.

Preparation of seeding culture. For preparation of active inoculum, spores were dislodged from induced fungal culture slants with $0.1 \%(\mathrm{v} / \mathrm{v})$ Tween 80 solution by gentle vortexing under aseptic condition. The suspension was recovered by aspiration and transferred into a sterile test tube. This suspension (contained $10^{6}-10^{7}$ spores $/ \mathrm{ml}$ ) was used as inoculum for cellulase production.

Submerged fermentation. An active inoculum $(2 \%, \mathrm{v} / \mathrm{v})$ was inoculated with $50 \mathrm{ml}$ of Mandel's broth [having the composition of $\mathrm{KH}_{2} \mathrm{PO}_{4}, 2.0 ;\left(\mathrm{NH}_{4}\right)_{2} \mathrm{SO}_{4}$, 1.4; Urea, 0.3; $\mathrm{MgSO}_{4} .7 \mathrm{H} 2 \mathrm{O}, 0.3$; $\mathrm{CaCl}_{2} .2 \mathrm{H}_{2} \mathrm{O}, 0.4$; $\mathrm{FeSO}_{4} \cdot 7 \mathrm{H}_{2} \mathrm{O}, 0.005 ; \mathrm{MnSO}_{4} \cdot \mathrm{H}_{2} \mathrm{O}, 0.0016 ; \mathrm{ZnSO}_{4} \cdot 7 \mathrm{H}_{2} \mathrm{O}$, 0.0014; $\mathrm{CoCl}_{2}, 0.0020$; Carboxymethyl cellulose, 10; $\mathrm{pH}-5.0]$ in Erlenmeyer flask and incubated in orbital shaker incubator $(120 \mathrm{rpm})$ for $120 \mathrm{~h}$ at $30^{\circ} \mathrm{C}$. 2-deoxy- 
D-glucose (DG) at concentration of $0.1-20 \mathrm{mg} / \mathrm{ml}$ was added to the media to study its effect on fungal growth and cellulase production. The culture supernatant obtained by centrifugation (at $5000 \times \mathrm{g}$ for $10 \mathrm{~min}$ ) was assayed for enzymatic activity. The growth kinetics was determined using Monod kinetic model (Lawford and Rouseau, 1993). The growth of fungus was determined on the basis of dry biomass $(\mathrm{mg} / \mathrm{ml})$, which was also used to calculate the value of specific growth rates as

$\mu\left(\mathrm{h}^{-1}\right)=\ln \left(\mathrm{m}_{\mathrm{t}} / \mathrm{m}_{\mathrm{o}}\right) / \mathrm{T}$

Where, $\mathrm{m}_{\mathrm{t}}$ is fungal biomass at a given time $\mathrm{T}(\mathrm{h})$, $\mathrm{m}_{\mathrm{o}}$ is the baseline spore biomass $(1 \mathrm{mg} / \mathrm{ml})$ at the start of the fermentation (Sterner and Elser, 2002).

Fermentation kinetics. Kinetic parameters for batch fermentation process in shake-flasks were determined according to the methods described by Lawford and Rousseau (1993). The representative batch culture kinetics like volumetric rate of cellulase production $\left(Q_{p}\right)$ was determined from the linear correlation between enzyme activity (U/flask) $v s$ fermentation time (h). Specific rate of enzyme production $\left(\mathrm{q}_{\mathrm{p}}\right)$ was determined as the maximum enzyme activity/g of fungal biomass/h. Biomass productivity $\left(\mathrm{Q}_{\mathrm{x}}\right.$; g dry biomass /flask/h) was determined from the slope of regression plot between biomass (g) vs. time of fermentation (Bokhari et al., 2008). Enzyme/biomass yield $\left(\mathrm{Y}_{\mathrm{E} / \mathrm{X}}\right.$ ) was estimated from the linear correlation between enzyme activity $(\mathrm{U} / \mathrm{ml})$ and biomass concentration $(\mathrm{mg} / \mathrm{ml})$.

Enzyme assay. (i) Endoglucanase or CMCase (E.C. 3.2.1.4) activity was determined by incubating $0.5 \mathrm{ml}$ of enzyme solution with $0.5 \mathrm{ml}$ of $1 \% \mathrm{CMC}$ (Sigma, St. Louis, MO, USA) in $0.05 \mathrm{M}$ sodium citrate buffer (pH 5.0) (Mandels et al., 1976).

(ii) Filter paper degrading activity (FPase) was determined using processed Whatman No 1 filter paper as substrate $(50 \mathrm{mg} / \mathrm{ml})$ according to the method of Wood and Bhat (1988). After incubation at $50^{\circ} \mathrm{C}$ for $30 \mathrm{~min}$, the reactions were stopped by adding $1 \mathrm{ml}$ of 3 , 5-dinitrosalicylic acid (DNS) reagent. Liberated reducing sugar was estimated colorimetrically according to the method of Miller (1959) using glucose as standard.

(iii) $\beta$-Glucosidase (E.C. 3.2.1.21) activity was determined by incubating $0.5 \mathrm{ml}$ of enzyme solution with $0.5 \mathrm{ml}$ of $1 \%$ cellobiose in $0.05 \mathrm{M}$ sodium citrate buffer (pH 5.0) at $50^{\circ} \mathrm{C}$ for $30 \mathrm{~min}$ and the liberated glucose was estimated by GOD-POD method (Bergmeyer 1974).

One unit of enzymatic activity (for above three enzymes) was defined as the amount of enzyme that released $1 \mu \mathrm{M}$ of reducing sugar (measured as glucose) $/ \mathrm{ml} / \mathrm{min}$ under specified assay conditions.

Determination of total carbohydrate and protein in the fungal biomass. $1 \mathrm{mg}$ of dry mycelia was placed in $1 \mathrm{ml}$ of $0.5 \mathrm{~N} \mathrm{NaOH}$ and kept in a boiling water bath for 20 min (Evsenko et al., 2009). The sample was then cooled, centrifuged and the carbohydrate content in the supernatant was measured using orcinol-sulphuric acid (Brown and Anderson, 1970). $3 \mathrm{ml}$ of orcinol reagent was added to $0.1 \mathrm{ml}$ reaction mixture containing different amounts of sample. The resulting reaction mixture was kept in a boiling water bath for $20 \mathrm{~min}$ to allow the color to develop and after cooling to room temperature the intensity of the color was measured at $540 \mathrm{~nm}$. The carbohydrate content of the sample was expressed in terms of glucose equivalent to a standard. Protein content was assayed following the method of Lowry et al., (1951) using bovine serum albumin as a standard.

Study on induction and repression of enzyme biosynthesis. The induction ratio, defined as the ratio of inducer activity and basal activity, was calculated using the following equation (Aguilar et al., 2001):

I.R. $=$ I.CA/B.CA

Where, I.R. is the induction ratio in cultures with CMC as sole carbon source; I.CA corresponds to induced cellulase activity and B.CA is the basal cellulase activity obtained from a culture using glucose as a sole carbon source. In the case of repression study, I.R. was calculated in the presence of both inducer and repressor (glucose).

The enzyme expression level was also studied by gel electrophoresis technique. During fungal growth in different concentration of glucose $(0.03-2.0 \%, \mathrm{w} / \mathrm{v})$, the culture supernatant was concentrated through acetone $(10 \%)$ precipitation and subjected to gel electrophoresis which was performed on a $10 \%$ sodium dodecyl sulfatepolyacrylamide gel in a electrophoresis chamber (BioRad, USA) as described by Laemmli (1970). The gel was run in tris-glycine buffer ( $\mathrm{pH} \mathrm{8.8)}$ for $3 \mathrm{~h}$ at $15 \mathrm{~mA}$, $100 \mathrm{~V}$. After electrophoresis, the protein was visualized by staining with Coomassie Brilliant Blue R-250.

For native gel electrophoresis, $0.1 \%$ carboxymethyl cellulose was added in $10 \%$ polyacrylamide gel with Tris-glycine buffer ( $\mathrm{pH}$ 8.8). After electrophoresis at $4^{\circ} \mathrm{C}$, the gel was incubated at $40^{\circ} \mathrm{C}$ for $1 \mathrm{~h}$ in $0.05 \mathrm{M}$ acetate buffer ( $\mathrm{pH}-5.0)$. The transparent zone that corresponded cellulose hydrolysis due to enzyme activity was visualized using $0.1 \%$ (w/v) Congo red.

Hydrolysis of rice straw. Ability of the crude cellulase to hydrolyze rice straw was evaluated using different enzyme dosages at varying $\mathrm{pH}(50 \mathrm{mM}$ citrate buffer, $\mathrm{pH} 4-8$ ). Hydrolysis reactions were performed in $250 \mathrm{ml}$ conical flasks that contained $1 \%$ substrate (rice straw) suspended in $50 \mathrm{ml}$ (final volume) of buffer, to which different doses of crude cellulase solution (FPU/g) were added. Hydrolysis was performed at $50^{\circ} \mathrm{C}$ in a water bath, for $12 \mathrm{~h}$. Glucose concentration in the hydrolysate was determined by DNS method. Saccharification (\%) was calculated as: reducing sugar $(\mathrm{mg} / \mathrm{ml}) \times 0.9 \times 100 /$ initial cellulose $(\mathrm{mg} / \mathrm{ml})$ in the substrate. Cellulose content in the rice straw was estimated by Updegraff method (1969). 
Scanning electron microscopic analysis. The structural differences in the morphology of rice straw before and after the enzyme pretreatment were visualized by JEOL JSM-5600 scanning electron microscope. Images of native and cellulase treated straw were taken at a magnification of $1000 \times$. The specimens to be coated were mounted on a conductive tape and coated with gold palladium using a JEOL-JFC-1200 fine coater and observed using a voltage of $25 \mathrm{kV}$.

Statistical analysis. The data represented here are the means of three replicates. The statistical significance of the results was analyzed using Sigma plot (USA) software.

\section{Results}

Isolation and molecular identification of cellulose producing fungi. A group of total 32 cellulose degrading fungal strains were initially isolated from different environmental samples. One fungal strain designated as AKB9 was finally selected on the basis of higher cellulase producing ability. For molecular identification of the selected strain, the PCR amplicon of the D2 region of LSU of $28 \mathrm{~S}$ rDNA was sequenced (611bp) and a phylogenetic tree was constructed using the Neighbor-Joining method (Saitou and Nei, 1987) (Fig. 1). The bootstrap consensus tree inferred from 500 replicates was taken to find out the evolutionary history of the taxa (Felsenstein, 1985). Based on nucleotide homology and phylogenetic analysis, the isolated fungal strain was identified as Aspergillus fumigatus ABK9 (NCBI GenBank accession number HM807348).

Time course of cellulase production. The kinetics of A. fumigatus $A B K 9$ growth and production of cellulolytic enzymes in shake flask batch culture was examined by growing cells in Mandel's broth as described in Materials and Methods. The results (Fig. 2) suggested that growth reached a maximum level $\left(\mathrm{X}_{\max }: 6.72 \mathrm{~g} / \mathrm{l}\right)$ with specific growth rate $\left(\mu_{\max }\right)$ of $0.126 / \mathrm{h}$ at $72 \mathrm{~h}$, that corresponded to the late logarithmic phase of fungal growth. Along with the increased biomass, highest level of CMCase, FPase and $\beta$-glucosidase in a ratio of 7:1:1.5 (98.37, 14.16 and $21.94 \mathrm{U} / \mathrm{ml}$ respectively) were also found at $72 \mathrm{~h}$ of fermentation (Fig. 2). Among these enzymes, the secretion of CMCase was started from the beginning of the growth. This result confirmed that the cellulase production was growth associated and the enzyme secretion was greatly dependent on the cell concentration and the specific growth rate of A. fumigatus AKB9.

Optimization of fermentation temperature and initial medium $\mathbf{~ p H}$. To find out the optimum temperature for cellulase biosynthesis, fermentation was carried out at different incubation temperatures $\left(20-40^{\circ} \mathrm{C}\right)$ for $72 \mathrm{~h}$. The highest final cell concentration $(6.68 \mathrm{~g} / \mathrm{l})$ and along with the highest specific rate of enzyme production $\left(\mathrm{q}_{\mathrm{p}}\right)$ of $191.58,23.6$ and $38.0 \mathrm{U} / \mathrm{g}$ cells/h for CMCase, FPase and $\beta$-glucosidase was achieved at an incubation temperature of $30^{\circ} \mathrm{C}$. But the values of growth yield $\left(\mathrm{X}_{\max }\right)$ and specific rate of enzyme production $\left(\mathrm{q}_{\mathrm{p}}\right)$ at incubation temperature of 25 and $35^{\circ} \mathrm{C}$ were considerably high (Fig. 3).

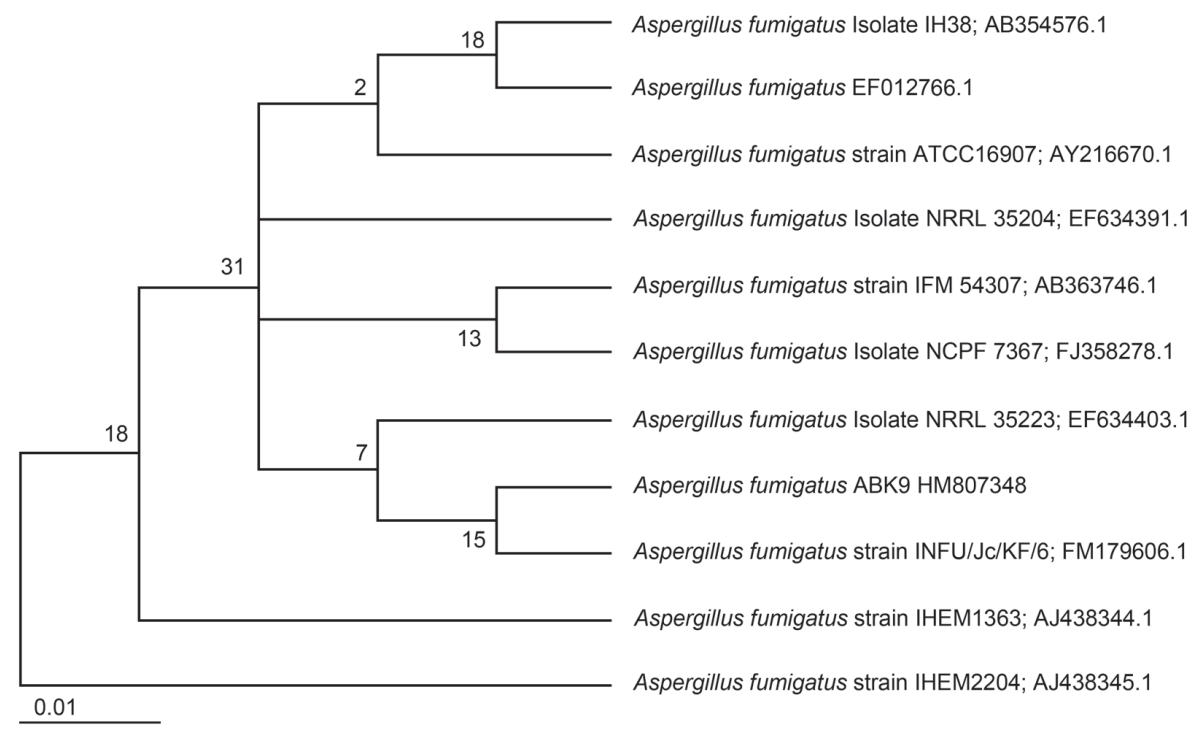

Fig. 1. Phylogenetic relationship of potent cellulolytic fungal isolate with neighboring strains. Neighbor-joining (NJ) tree based on 28SrDNA gene sequences showing the relationships between Aspergillus fumigatus ABK9 and other closest NCBI (mega BLAST) relatives. 


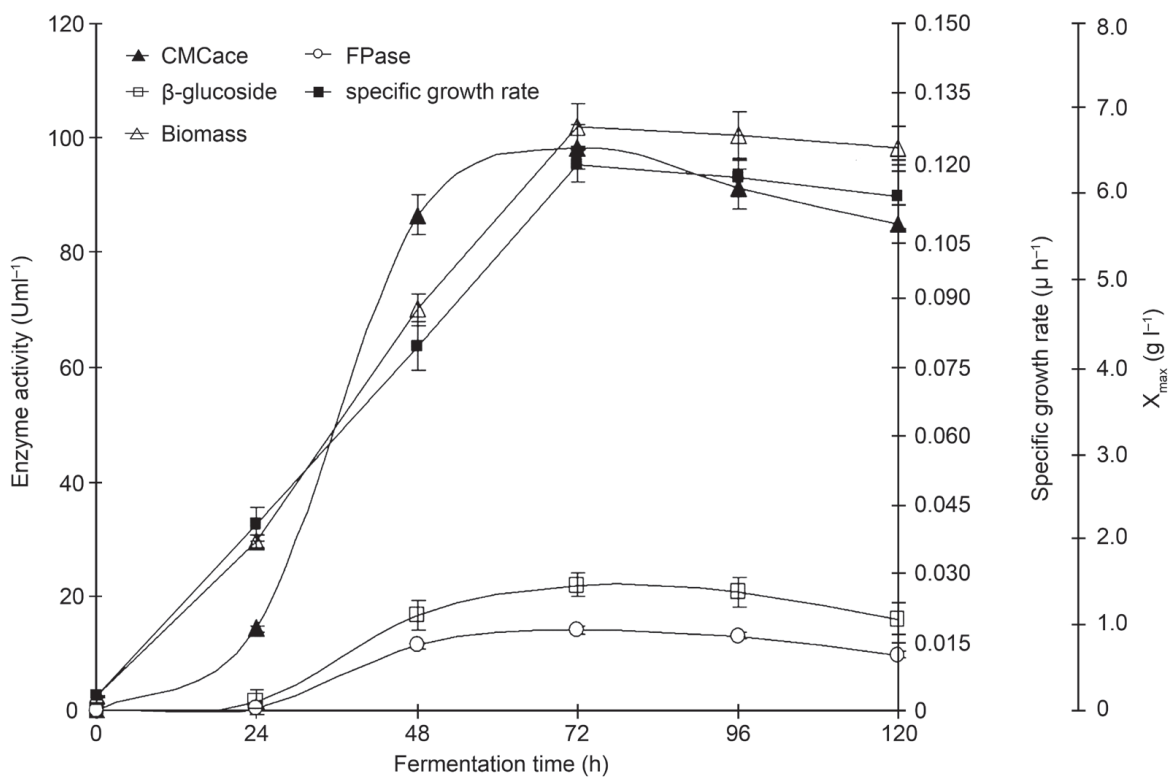

Fig. 2. Time course of cellulases production by A. fumigatus ABK9 under submerged fermentation.

Fermentation was carried out in Mandel's broth medium ( $\mathrm{pH} \mathrm{5.0)}$ ) with $1 \%$ carboxymethyl cellulose (CMC) at $30^{\circ} \mathrm{C}$ for $120 \mathrm{~h}$ under shaking conditions $(120 \mathrm{rpm})$. Fresh spore suspension $(2 \% \mathrm{v} / \mathrm{v} ; 2 \mathrm{mg} / \mathrm{ml})$ as inoculum was added to the culture medium.

The effect of initial culture $\mathrm{pH}$ on growth of A. fumigatus AKB9 and cellulase production is summarized in Fig. 4. A notable amount of enzyme synthesis was found in a broad range of medium $\mathrm{pH}$ from 4.0 to 7.0 (Fig. 4). The highest final cell concentration $\left(\mathrm{X}_{\max }: 6.84 \mathrm{~g} / \mathrm{l}\right)$ was obtained at initial $\mathrm{pH}$ of 5.0 and corresponded to the highest cellulase production $\left(\mathrm{q}_{\mathrm{p}}\right.$ for CMCase, FPase and $\beta$-glucosidase was 228.4, 26.6 and $35.2 \mathrm{U} / \mathrm{g}$ cells/h).

Effect of agitation on cellulase production. To study the effect of agitation on cellulase yield, fermenta-

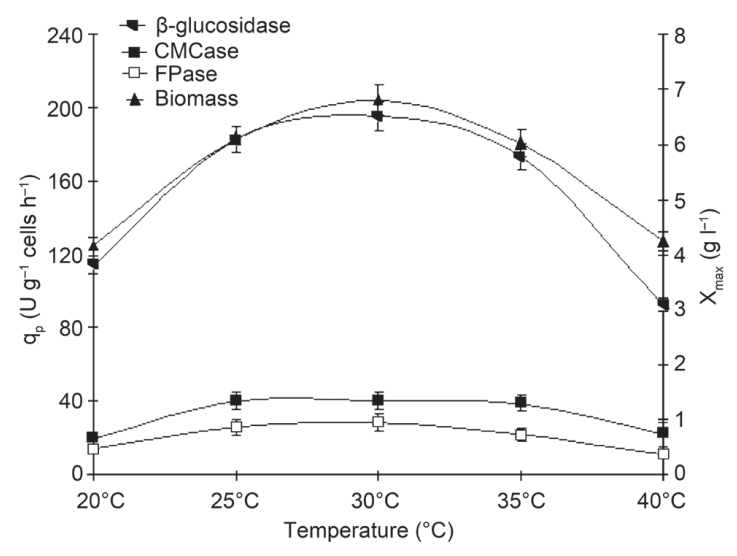

Fig. 3. Effect of fermentation temperature on the specific rate of cellulases production $\left(\mathrm{q}_{\mathrm{p}}\right)$ by A.fumigatus ABK9. Submerged fermentation was carried out at initial $\mathrm{pH} 5.0$ for $72 \mathrm{~h}$ in Mandel's broth medium with $1 \%$ carboxymethyl cellulose (CMC).

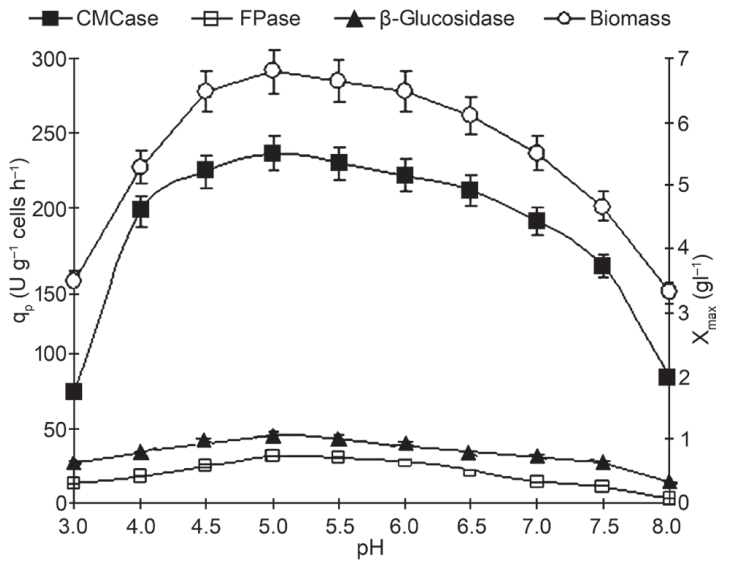

Fig. 4. Effect of initial medium $\mathrm{pH}$ on the specific rate of cellulases production $\left(\mathrm{q}_{\mathrm{p}}\right)$ by A.fumigatus ABK9. Submerged fermentation was carried out at $30^{\circ} \mathrm{C}$ for $72 \mathrm{~h}$ in Mandel's broth medium with $1 \%$ carboxymethyl cellulose (CMC). Initial $\mathrm{pH}$ of the medium was adjusted by adding $0.1 \mathrm{~N} \mathrm{HCl}$ of $\mathrm{NaOH}$.

tion was carried out at different rpm (0-200) in orbital shaker incubator. Fig. 5 indicates that with the increase in agitation speed up to $120 \mathrm{rpm}$, production yield gradually increased with highest CMCase, FPase and $\beta$-glucosidase activities of $120.4,18.3$ and $20.2 \mathrm{U} / \mathrm{ml}$.

Effect of carbon sources on cellulase production. Comparison of fermentation kinetics related to enzyme production and growth of the organism were studied in presence of different types of carbohydrate like Avicel, carboxymethyl cellulose (CMC), cellobiose, 


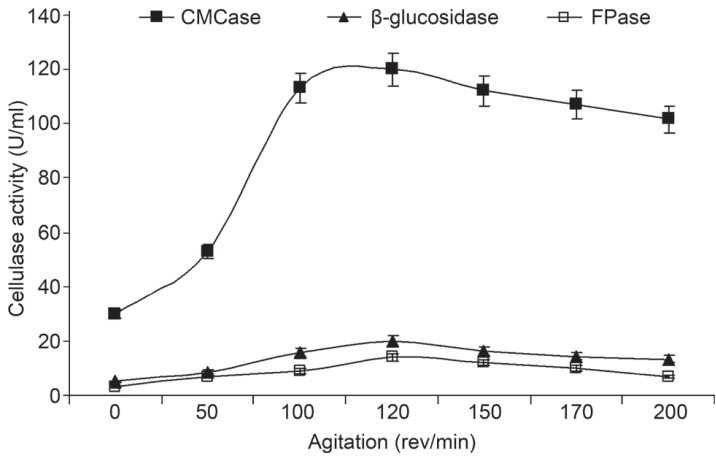

Fig. 5. Effect of agitation on cellulase production under submerged fermentation by A. fumigatus ABK9. Submerged fermentation was carried out at $\mathrm{pH} 5.0$ for $72 \mathrm{~h}$ in Mandel's broth medium with $1 \%$ carboxymethyl cellulose (CMC).

lactose and glucose $(1 \%, \mathrm{w} / \mathrm{v})$ in the culture media in an attempt to select the appropriate carbon source as well as inducer for biosynthesis of cellulolytic enzymes by A. fumigatus ABK9.

Table I shows that the specific rate $\left(\mathrm{q}_{\mathrm{p}}\right)$ of CMCase and FPase production was maximum (210.3 and
24.6 U/g cells/h) in presence of CMC followed by Avicel, whereas, that of $\beta$-glucosidase synthesis was maximum $(35.32 \mathrm{U} / \mathrm{g}$ cells $/ \mathrm{h})$ in presence of CMC followed by cellobiose. The volumetric rate of enzyme production $\left(\mathrm{Q}_{\mathrm{p}}\right)$ as well as enzyme / biomass yield $\left(\mathrm{Y}_{\mathrm{E} / \mathrm{X}}\right)$ in the case of all cellulase fractions were also increased when CMC was present in the culture media as a carbon source. The presence of easily utilizable carbohydrate like lactose and glucose supported highest growth $\left(\mathrm{Q}_{\mathrm{x}} 4.16\right.$ and $6.9 \mathrm{mg} / \mathrm{flask} / \mathrm{h} ; \mathrm{X}_{\max }, 7$ and $9 \mathrm{~g} / \mathrm{l} ; \mu, 0.122$ and $0.126 / \mathrm{h}$, respectively), but were repressive to cellulase biosynthesis with a very low enzyme/biomass yield $\left(\mathrm{Y}_{\mathrm{E} / \mathrm{X}}\right)$ ratio.

Effect of 2-deoxy-D-glucose on fungal growth and enzyme production. With the increase in 2-deoxy-Dglucose concentrations, the hyphal growth of A. fumigatus gradually decreased and at growth was severely hampered at concentrations greater than $10 \mathrm{mg} / \mathrm{mL}$ (Table II). In the presence of 2-deoxy-D-glucose, the carbohydrate to protein ratio decreased up to its concentration of $0.5 \mathrm{mg} / \mathrm{ml}$ and then gradually increased. Mycelial growth and rate of carbohydrate utilization during fermentation was also decreased with increas-

Table I

Fermentation kinetics of Aspergillus fumigatus ABK9 for cellulases production following growth on different carbon sources in submerged fermentation [fermentation period: $72 \mathrm{~h}$, incubation temperature: $30^{\circ} \mathrm{C}$, initial medium $\mathrm{pH}: 5.0$ and shaking speed: $100 \mathrm{rpm}$ ].

\begin{tabular}{|c|c|c|c|c|c|c|c|c|c|c|c|c|}
\hline \multirow[b]{2}{*}{$\begin{array}{l}\text { Carbon Source } \\
(1 \%, w / v)\end{array}$} & \multicolumn{3}{|c|}{ Growth related parameters } & \multicolumn{3}{|c|}{ CMCase } & \multicolumn{3}{|c|}{ FPase } & \multicolumn{3}{|c|}{$\beta$-glucosidase } \\
\hline & $\begin{array}{c}\mathrm{Q}_{\mathrm{x}} \\
(\mathrm{mg} / \\
\left.\text { flask/ }{ }^{1} \mathrm{~h}\right)\end{array}$ & $\begin{array}{l}\mathrm{X}_{\max } \\
(\mathrm{g} / \mathrm{l})\end{array}$ & $\begin{array}{c}\mu \\
(/ \mathrm{h})\end{array}$ & $\begin{array}{c}\mathrm{Q}_{\mathrm{p}} \\
(\mathrm{U} / \\
\text { flask/h) }\end{array}$ & $\begin{array}{c}\mathrm{q}_{\mathrm{p}} \\
(\mathrm{U} / \mathrm{g} \\
\text { cells/h) }\end{array}$ & $\begin{array}{c}\mathrm{Y}_{\mathrm{E} / \mathrm{X}} \\
(\mathrm{U} / \mathrm{mg})\end{array}$ & $\begin{array}{c}\mathrm{Q}_{\mathrm{p}} \\
(\mathrm{U} / \\
\text { flask/h) }\end{array}$ & $\begin{array}{c}\mathrm{q}_{\mathrm{p}} \\
(\mathrm{U} / \mathrm{g} \\
\text { cells/h) }\end{array}$ & $\begin{array}{c}\mathrm{Y}_{\mathrm{E} / \mathrm{X}} \\
(\mathrm{U} / \mathrm{mg})\end{array}$ & $\begin{array}{c}\mathrm{Q}_{\mathrm{p}} \\
(\mathrm{U} / \\
\text { flask/h) }\end{array}$ & $\begin{array}{c}\mathrm{q}_{\mathrm{p}} \\
(\mathrm{U} / \mathrm{g} \\
\text { cells/h) }\end{array}$ & $\begin{array}{c}\mathrm{Y}_{\mathrm{E} / \mathrm{X}} \\
(\mathrm{U} / \mathrm{mg})\end{array}$ \\
\hline Cellulose (CMC) & $4.86^{\mathrm{b}}$ & $7^{\mathrm{b}}$ & $0.123^{\mathrm{a}}$ & $73.61^{\mathrm{a}}$ & $210.3^{\mathrm{a}}$ & $14.04^{\mathrm{a}}$ & $8.61^{\mathrm{a}}$ & $24.6^{\mathrm{a}}$ & $1.77^{\mathrm{a}}$ & $12.36^{\mathrm{a}}$ & $35.32^{\mathrm{a}}$ & $2.54^{\mathrm{a}}$ \\
\hline Avicel & $3.41^{\mathrm{d}}$ & $5^{d}$ & $0.118^{\mathrm{a}}$ & $46.34^{\mathrm{c}}$ & $185.36^{\mathrm{b}}$ & $13.34^{\mathrm{b}}$ & $5.9^{c}$ & $23.6^{\mathrm{b}}$ & $1.7^{\mathrm{a}}$ & $7.99^{d}$ & $31.90^{c}$ & $2.3^{\mathrm{b}}$ \\
\hline Cellobiose & $4.16^{\mathrm{c}}$ & $6^{c}$ & $0.120^{\mathrm{a}}$ & $46.70^{c}$ & $155.69^{d}$ & $13.44^{\mathrm{b}}$ & $5.69^{c}$ & $18.9^{c}$ & $1.37^{\mathrm{c}}$ & $10.42^{\mathrm{b}}$ & $34.72^{\mathrm{b}}$ & $2.5^{\mathrm{a}}$ \\
\hline Lactose & $4.16^{\mathrm{c}}$ & $7^{\mathrm{b}}$ & $0.122^{\mathrm{a}}$ & $59.01^{\mathrm{b}}$ & $168.65^{c}$ & $12.14^{\mathrm{c}}$ & $7.29^{\mathrm{b}}$ & $24.3^{\mathrm{a}}$ & $1.5^{\mathrm{b}}$ & $9.38^{\mathrm{c}}$ & $26.79^{\mathrm{d}}$ & $1.93^{\mathrm{c}}$ \\
\hline Glucose & $6.90^{\mathrm{a}}$ & $9^{a}$ & $0.126^{\mathrm{a}}$ & $3.6^{\mathrm{d}}$ & $4.93^{\mathrm{d}}$ & $0.36^{\mathrm{d}}$ & $0.62^{\mathrm{d}}$ & $0.62^{\mathrm{d}}$ & $0.04^{\mathrm{d}}$ & $0.63^{\mathrm{c}}$ & $1.38^{\mathrm{c}}$ & $0.10^{\mathrm{d}}$ \\
\hline
\end{tabular}

Rate of cell mass formation $\left(\mathrm{Q}_{\mathrm{x}}\right)$, maximum biomass formation $\left(\mathrm{X}_{\mathrm{max}}\right)$, specific growth rate $(\mu)$, enzyme formation rate $\left(\mathrm{Q}_{\mathrm{p}}\right)$, specific rate of enzyme production $\left(\mathrm{q}_{\mathrm{p}}\right)$, enzyme/biomass yield $\left(\mathrm{Y}_{\mathrm{E} / \mathrm{X}}\right)$. Each value is a mean of three replicates. Values followed by different superscript letters (a-d) differ significantly at $\mathrm{P} \leq 0.05$.

Table II

Effect of 2-Deoxy glucose on fungal growth, substrate utilization and cellulases production by A. fumigatus ABK 9 after $72 \mathrm{~h}$ of fermentation.

\begin{tabular}{|c|c|c|c|c|c|c|}
\hline Sample & $\begin{array}{c}\text { Growth } \\
\mathrm{Q}_{\mathrm{x}}(\mathrm{mg} / \text { flask/h) }\end{array}$ & $\begin{array}{c}\text { Carbohydrate/ } \\
\text { protein }\end{array}$ & $\begin{array}{c}\text { Residual sugar } \\
(\%)\end{array}$ & $\begin{array}{c}\text { CMCase } \\
\text { activity }(\mathrm{U} / \mathrm{ml})\end{array}$ & $\begin{array}{c}\text { FPase activity } \\
(\mathrm{U} / \mathrm{ml})\end{array}$ & $\begin{array}{c}\beta \text {-glucosidase } \\
\text { activity }(\mathrm{U} / \mathrm{ml})\end{array}$ \\
\hline Control $(\mathrm{CMC} 1 \%)$ & 4.86 & 1.66 & 23.3 & 106.4 & 12.4 & 17.8 \\
\hline C+ DG $(0.1 \mathrm{mg} / \mathrm{ml})$ & 3.52 & 1.54 & 25.2 & 112.3 & 14.6 & 21.6 \\
\hline C+ DG $(0.3 \mathrm{mg} / \mathrm{ml})$ & 2.9 & 1.41 & 36.1 & 124.2 & 18.3 & 26.3 \\
\hline C+ DG $(0.5 \mathrm{mg} / \mathrm{ml})$ & 2.22 & 1.13 & 42.3 & 132.2 & 21.3 & 28.9 \\
\hline C+ DG $(10 \mathrm{mg} / \mathrm{ml})$ & 1.25 & 1.56 & 56.7 & 92.1 & 13.3 & 22.1 \\
\hline C+ DG $(15 \mathrm{mg} / \mathrm{ml})$ & 0.85 & 1.77 & 62.9 & 57.3 & 8.3 & 13.4 \\
\hline C+ DG $(20 \mathrm{mg} / \mathrm{ml})$ & 0.68 & 2.1 & 70.9 & 21.6 & 5.5 & 7.7 \\
\hline
\end{tabular}




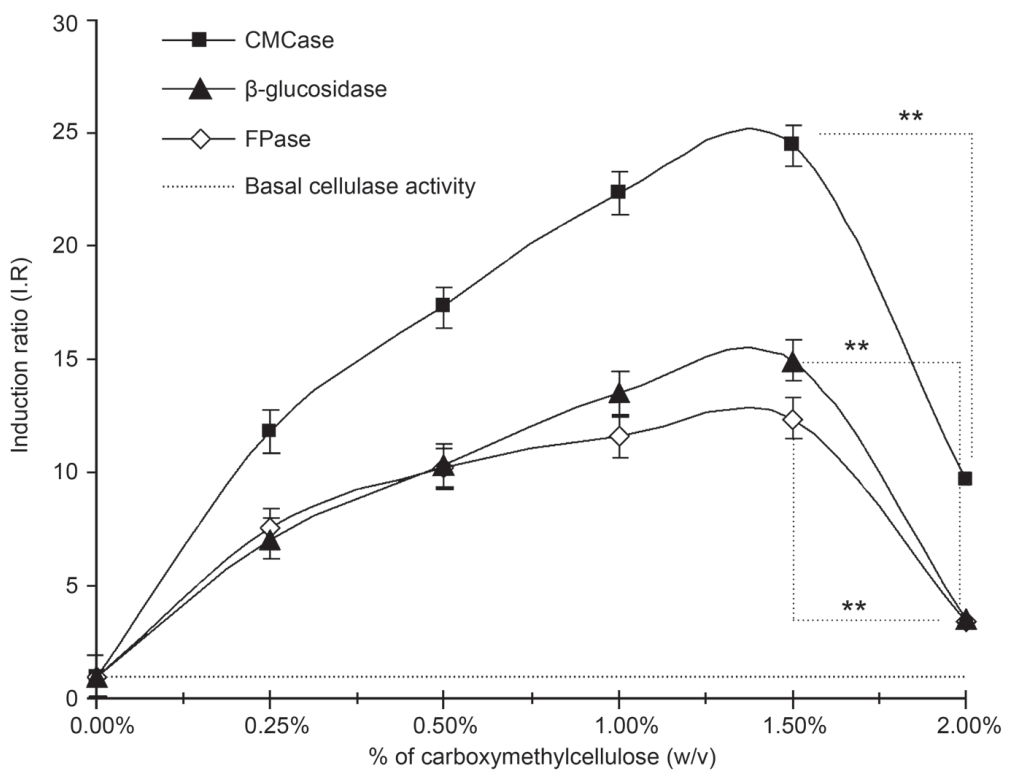

Fig. 6. Induction patterns of cellulases by A. fumigatus ABK9 with carboxymethyl cellulose (CMC) as sole carbon source. $\left(^{*}\right)$ indicates significant difference at $\mathrm{P}<0.05$. Statistical analysis was done by Sigma Plot statistical software.

ing concentration of 2-deoxy-D-glucose. The maximum production of cellulolytic enzymes viz, CMCase, FPase and $\beta$-glucosidase activities (132.2, 21.3 and $28.9 \mathrm{U} / \mathrm{ml}$ respectively) were found in the presence of 2-deoxy-D-glucose concentration of $0.5 \mathrm{mg} / \mathrm{ml}$ supplemented with $1 \%$ of carboxymethyl cellulose after $72 \mathrm{~h}$ of fermentation.

Induction/repression ratio of cellulolytic enzymes. The biosynthesis pattern of different cellulolytic enzymes at varied CMC concentrations (0.25-2\%; $\mathrm{w} / \mathrm{v})$ was examined under submerged fermentation and is represented in Fig. 6. Maximum induction ratios of 24.45, 12.35 and 14.9 for CMCase, FPase and $\beta$-glucosidase activities respectively were found in the presence of $1.5 \% \mathrm{CMC}$. The induction of these enzymes declined significantly when CMC concentration was increased beyond this level. The repression ratio (inverse to induction ratio) of cellulases biosynthesis was also studied by addition of glucose $(0-2 \%$, w/v) in the induced culture media with $1.5 \%(\mathrm{w} / \mathrm{v})$ CMC. Fig. 7 depicts that the organism was quite resistant to the 'glucose effect' up to the concentration of $0.5 \mathrm{~g} \%$, but above this level catabolite repression was significantly increased in dose dependent manner. Electrophoresis analysis also reflected that cellulase expression was declined in correlation with the higher concentration of glucose.

Effect of C: $\mathrm{P}$ ratio on cellulase synthesis. Among the different inorganic phosphate sources, $\mathrm{KH}_{2} \mathrm{PO}_{4}$ in $0.2 \mathrm{~g} \%$ concentration supported maximum enzyme synthesis. To achieve the desired C:P ratio, 1\% (w/v) CMC was used as carbon source, while the amount of $\mathrm{KH}_{2} \mathrm{PO}_{4}$ was varied. It was found that $\mathrm{C}: \mathrm{P}$ ratio of 4.0 favoured maximum yield of cellulase $(125.66,16.4$ and $24.7 \mathrm{U} / \mathrm{ml}$ for CMCase, FPase and $\beta$-glucosidase respectively), but above or below this value, the enzymes synthesis was suppressed (Fig. 8).

Effect of C: $\mathrm{N}$ ratio on cellulases production. Different inorganic and organic nitrogen sources $(0.3 \%$, $\mathrm{w} / \mathrm{v}$ ) were supplemented in Mandel's broth and it was found that production of cellulolytic enzymes was greatly influenced by the type of nitrogen source used. Yeast extract exhibited the highest yield of all three cellulolytic enzymes. To accomplish the particular C: $\mathrm{N}$ ratio, 1\% CMC was used as carbon source while the amount of yeast extract was varied. Fig. 9 shows that maximum yield of cellulolytic enzymes $(126.37,17.5$, and $26.0 \mathrm{U} / \mathrm{ml}$ for CMCase, FPase and $\beta$-glucosidase) was supported at $\mathrm{C}$ : $\mathrm{N}$ ratio of 10.0 .

Hydrolysis of rice straw using the crude enzyme. Using the Updegraff method, cellulose content in the sun-dried rice straw (pretreated with $1 \% \mathrm{NaOH}$ ) was estimated to be around $30 \%$. Hydrolysis of $1 \%$ rice straw using crude enzyme dosage (FPase activity) of $10 \mathrm{IU} / \mathrm{g}$ rice straw yielded saccharification efficiency of $46.3 \%$ in $12 \mathrm{~h}$ at $\mathrm{pH}$ 6.0. With the increase in $\mathrm{pH}$ values, the saccharification yield gradually decreased (Fig. 10).

Supramolecular structural changes in the untreated and enzyme treated rice straw were observed using scanning electronic microscope (SEM). The SEM images (Fig. 11) showed that the native structure of rice straw was opened during the enzymatic treatment, 


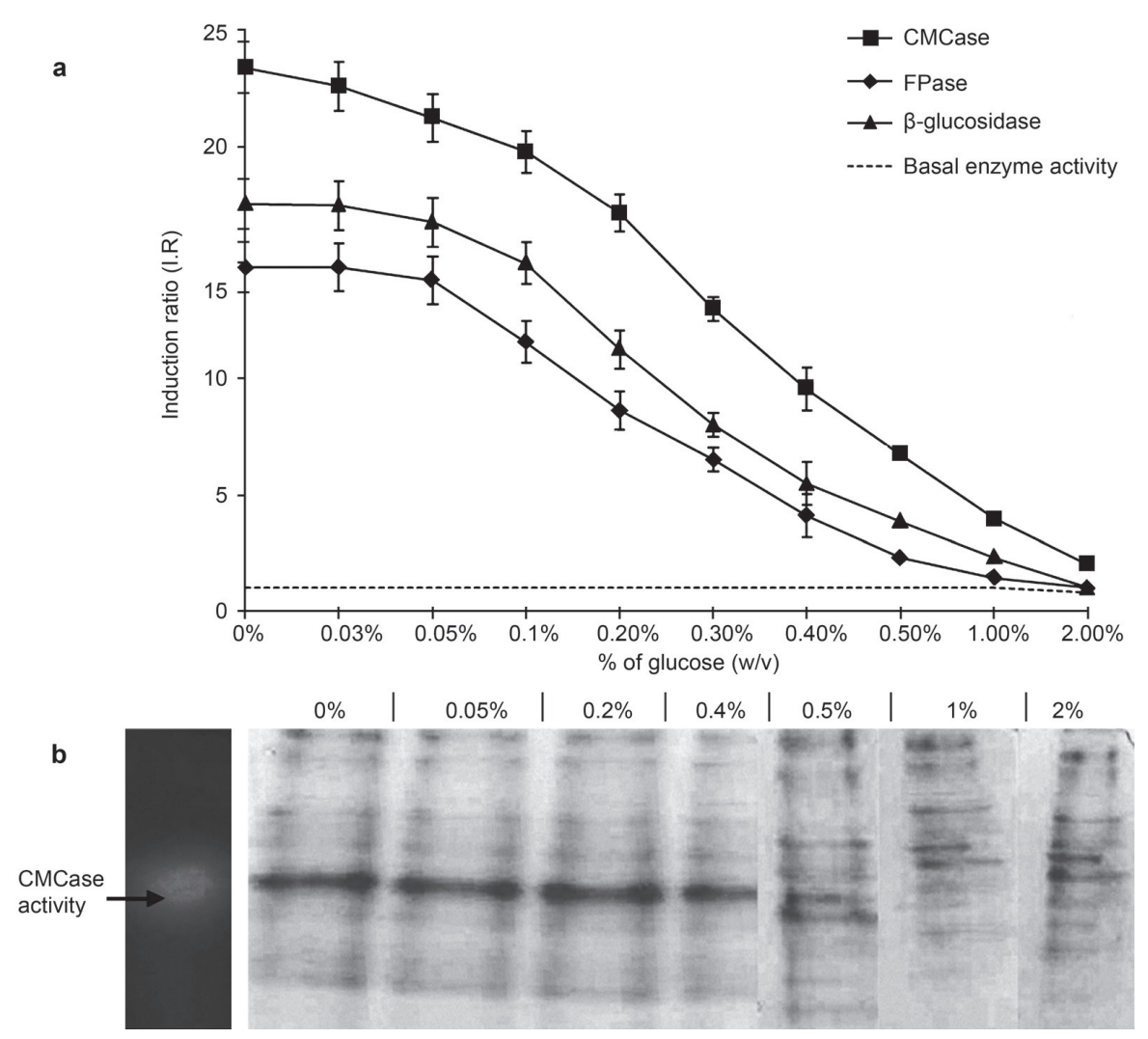

Fig. 7. Effect of varying glucose concentrations on the induction patterns of cellulases by A. fumigatus ABK9 in 1\% carboxymethylcellulose (CMC) containing Mandels media (a). Native polyacrylamide gel electrophoresis band and zymogram analysis of the crude enzymes indicate the pattern of induction in the medium (b).
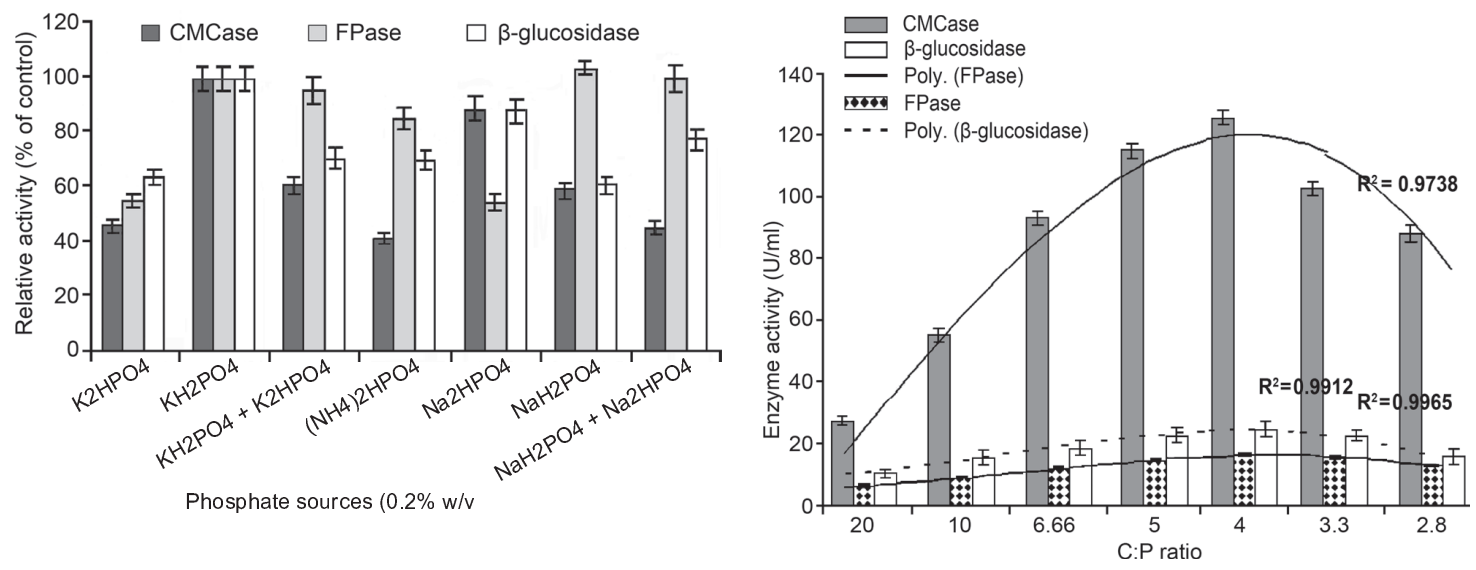

Fig. 8. Effect of different phosphate sources (0.2\%) on cellulases production by A. fumigatus ABK9 under submerged fermentation (a). To achieve the desired C: P ratio, $1 \%(\mathrm{w} / \mathrm{v}) \mathrm{CMC}$ was used as carbon source, while the amount of phosphate source was varied (b)

which enhanced the surface area for further degradation (Cybulska et al., 2010). The cellulosic fragments and breaks along the cellulosic fibers could be observed at a magnification of $1000 \times$, which meant that the cellulase broke enough glucosidal bonds to weaken the microfibril surfaces and caused splitting.

\section{Discussion}

Generally synergistic activities of the cellulolytic enzymes are required for the complete hydrolysis of cellulose, and for this, a crude cellulase preparation is considered advantageous over the purified enzymes 

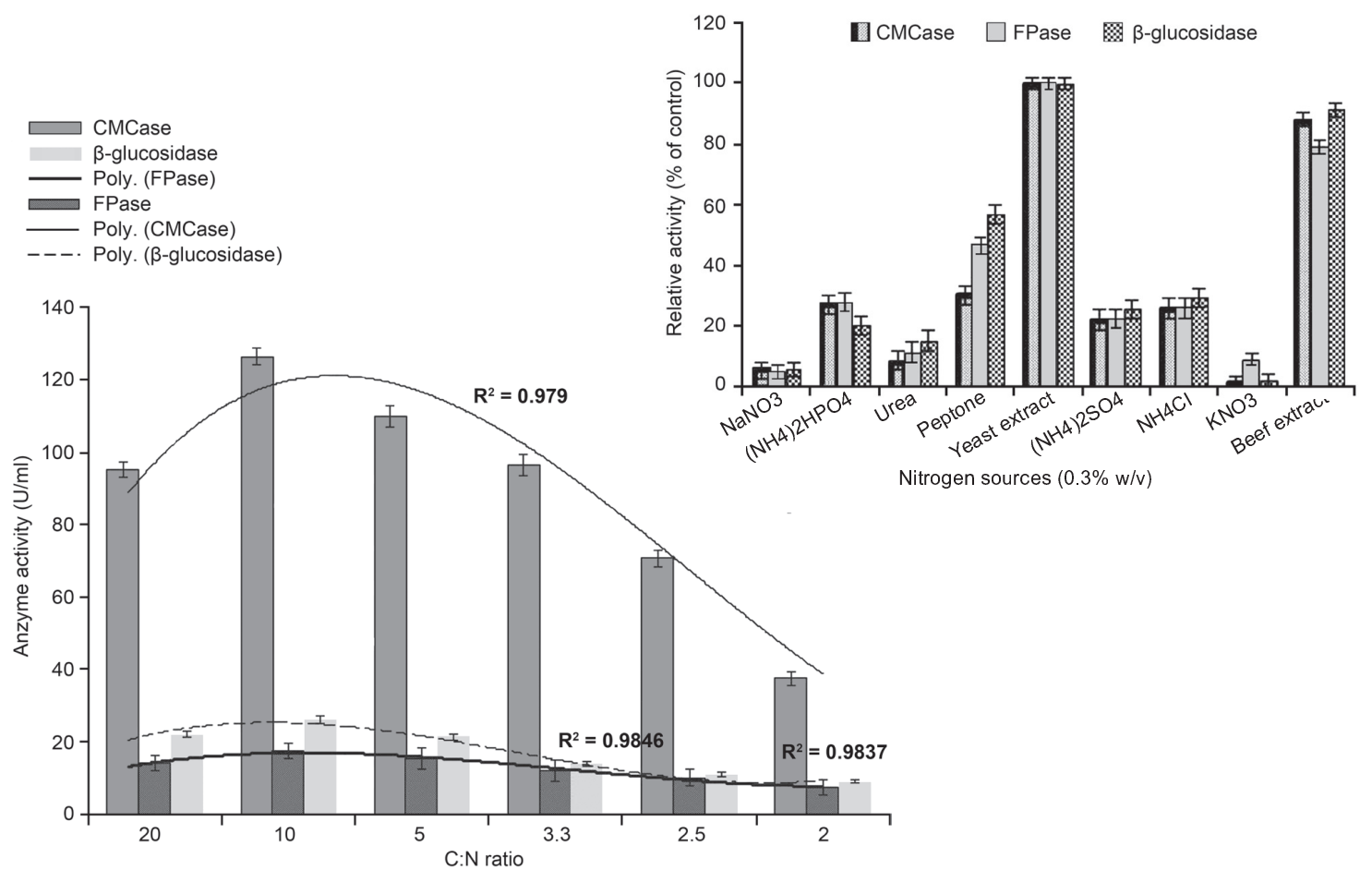

Fig. 9. Effect of different nitrogen sources (0.3\%) on cellulases production by A. fumigatus ABK9 under submerged fermentation (a) To achieve the desired C: $\mathrm{N}$ ratio, $1 \%(\mathrm{w} / \mathrm{v}) \mathrm{CMC}$ was used as carbon source, while the amount of nitrogen source was varied (b).

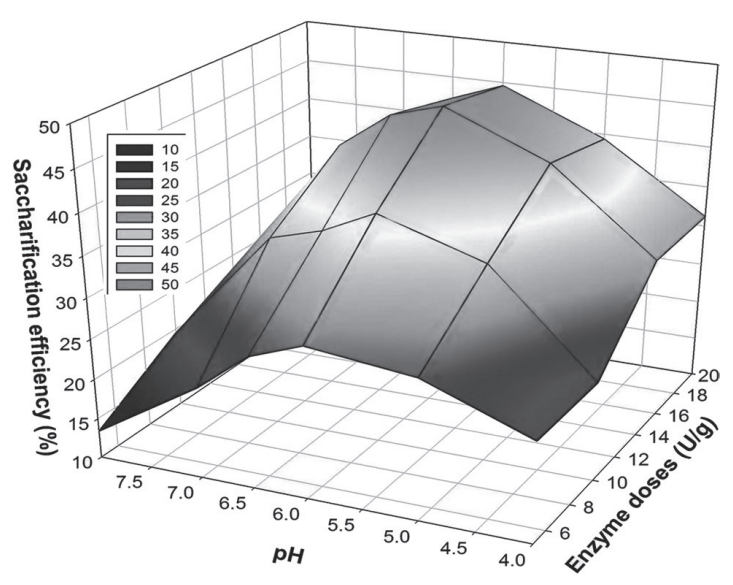

Fig. 10. Study on rice straw saccharification efficiency of different doses of cellulase (FPase activity, U/g) at varying $\mathrm{pHs}$.

(Wilson, 2009). Crude cellulase preparation with high proportionate of FPase is beneficial for fast saccharification process (Goodell et al., 1997; Juhasz et al., 2005; Gao et al., 2008), but literature on such type of preparation is very scarce (Table III).

In this study, after extensive screening one potent cellulolytic fungal isolate was selected, which was identified on the basis of morphological and 28S rDNA analysis as Aspergillus fumigatus ABK9. Fungi are well

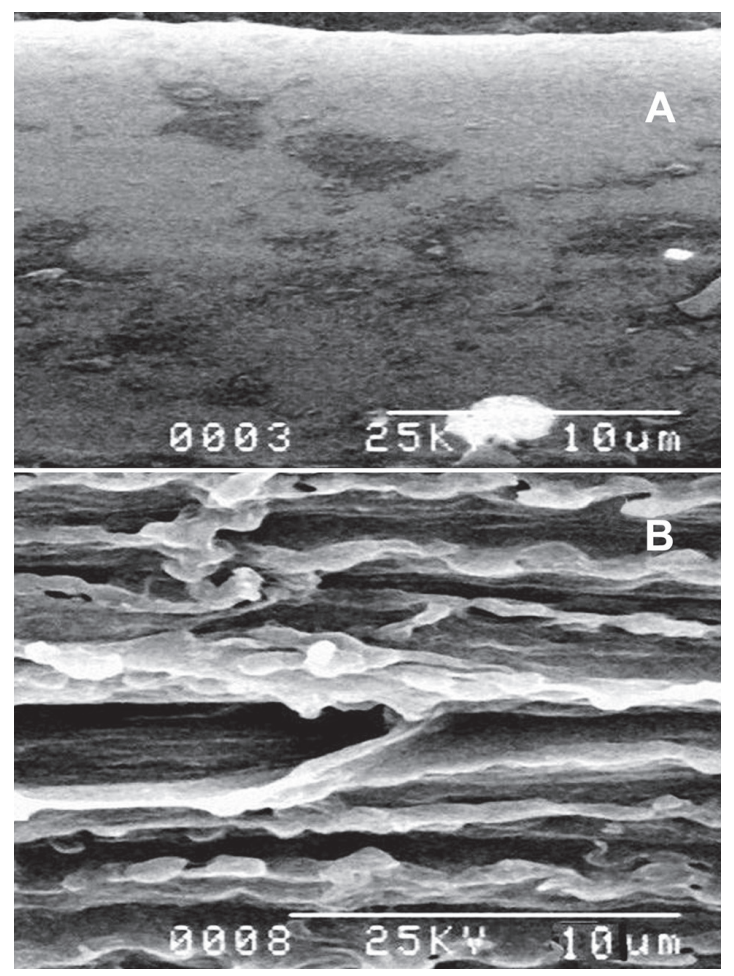

Fig. 11. Scanning electron micrograph of untreated (A) and enzyme treated (B) wheat straw. 
Table III

A comparative account of cellulases (CMCase, FPase and $\beta$-glucosidase) production by the newly isolated fungal strain and other related fungus, cited from literature.

\begin{tabular}{|c|c|c|c|c|}
\hline Organism & Substrate & Cultural condition & Enzyme activity & Reference \\
\hline Aspergillus fumigates ABK9 & Carboxymethyl cellulose & $\begin{array}{l}\text { Submerged fermentation } \\
\text { (SMF) shake flask }\end{array}$ & $\begin{array}{l}\text { CMCase: } 126.37 \mathrm{U} / \mathrm{ml} \\
\text { FPase: } 17.5 \mathrm{U} / \mathrm{ml} \\
\beta \text {-Glucosidase: } 26.0 \mathrm{U} / \mathrm{ml}\end{array}$ & This work \\
\hline Trichoderma reesei & Cellulose powder & SMF, stirred tank bioreactor & FPase: $69.8 \mathrm{U} / \mathrm{l} / \mathrm{h}$ & $\begin{array}{l}\text { (Ahamed and } \\
\text { Vermette, 2009) }\end{array}$ \\
\hline $\begin{array}{l}\text { Hypocrea jecorina Rut C30 } \\
\text { and Candida } \\
\text { Bombicola (Co-culture) }\end{array}$ & Glycerol and soybean oil & SMF, shake flask & FPase: $0.5 \mathrm{U} / \mathrm{ml}$ ) & (Lo and Ju, 2009) \\
\hline $\begin{array}{l}\text { Trichoderma reesei } \\
\text { NCIM } 1052\end{array}$ & $\begin{array}{l}\text { Water } \\
\text { Hyacinth }\end{array}$ & SMF, shake flask & FPase: $0.22 \pm 0.04 \mathrm{U} / \mathrm{ml}$ & (Pradnya et al., 2008) \\
\hline Penicillium occitanis & Paper pulp & $\begin{array}{l}\text { SMF- Fed batch } \\
\text { 20L fermentor }\end{array}$ & $\begin{array}{l}\text { CMCase: } 21 \mathrm{U} / \mathrm{ml} \\
\text { FPase: } 23 \mathrm{U} / \mathrm{ml}\end{array}$ & (Klemn et al., 2005) \\
\hline Trichoderma reesei & Sugar cane bagasse & SMF, shake flask & $\begin{array}{l}\text { CMCase: } 33.8 \mathrm{U} / \mathrm{ml} \\
\text { FPase: } 0.88 \mathrm{U} / \mathrm{ml} \\
\beta \text {-Glucosidase: } 0.33 \mathrm{U} / \mathrm{ml}\end{array}$ & (Adsul et al., 2004) \\
\hline $\begin{array}{l}\text { Aspergillus terreus and } \\
\text { Trichoderma reesei } \\
\text { (Co-culture) }\end{array}$ & Sugar cane bagasse & SMF, shake flask & FPase: $0.6 \mathrm{U} / \mathrm{ml}$ & $\begin{array}{l}\text { (Muhannad et al., } \\
\text { 2001) }\end{array}$ \\
\hline
\end{tabular}

known agents for decomposition of cellulosic organic matters and Aspergillus produces wide range of enzymes capable of degrading plant cell wall polysaccharides. A wide range of Aspergillus sp has been identified to possess all components of the cellulose enzymes system (Vries and Visser, 2001), which is in agreement with the current study.

Incubation time of a fermentation experiment has a direct relationship with the production of microbial extracellular enzymes. The growth related enzyme synthesis indicates (Fig. 2) that cellulase production was proportionately increased with cell biomass (growth associated). Organism synthesized higher quantity of cellulases in the late logarithmic phase of growth $(72 \mathrm{~h})$. The highest biomass $\left(\mathrm{X}_{\max }\right)$ and specific growth rate $\left(\mu_{\max }\right)$ of the organism was also obtained at this period. This indicated higher biomass related to the highest accumulation of enzyme in the culture broth. Fermentation time for maximum cellulases production by A.fumigatus ABK9 was also shorter than some other cellulolytic fungi like Tricothecium, and Penicillium (Agnihotri et al., 2010). The maximum yield of different fractions of cellulase particularly the content of FPase obtained from A. fumigatus ABK9 was higher than some previously reported filamentous fungi like Aspergillus, Trichoderma, Penicillium, etc (Table II). It is also interesting to note that during the course of fermentation endoglucanase activity was induced earlier than $\beta$-glucosidase activity, since it acts on the poly- meric cellulose, which is abundant at the beginning of fermentation (Fig. 2). As this substrate hydrolyzed into short chain oligosaccharides, $\beta$-glucosidase induction increased and became stable.

The $\mathrm{pH}$ of the culture medium and incubation temperature are the most important physical regulatory factors in most studies on microbial cultures. The incubation temperature of $30^{\circ} \mathrm{C}$ and initial medium $\mathrm{pH}$ of 4.5-5.5 were found most stimulatory for specific rate of cellulase productivity $\left(\mathrm{q}_{\mathrm{p}}\right)$ and growth $\left(\mathrm{X}_{\max }\right)$ of A. fumigatus ABK9. Present experiments also demonstrated that the organism was able to synthesize a good amount of enzyme in wide range of $\mathrm{pH}$ from 4.0 to 7.0 and at 25 to $35^{\circ} \mathrm{C}$. Thus this mesophilic fungus will be very suitable for the large scale production of cellulolytic enzymes at room's environment (Agnihotri et al., 2010). Rajoka et al. (2006) also mentioned that optimum $\mathrm{pH}$ for fungal growth lies around 4.5 and 5.5.

Agitation and aeration are generally used to meet the oxygen demand, uniform mixing and distribution of nutrients during fermentation process. Increased agitation helps to overcome resistance to the transfer of oxygen into the medium and then into the microbial cells (Bartholomew et al., 1950) providing a large gas liquid interface surface area could lead to an increase in the rate of oxygen transfer in the fermentation broth. In the case of A. fumigatus ABK9, agitation at $120 \mathrm{rev} /$ min supported maximum cellulases secretion, above which production decreased (Fig. 3). 
Growth rates and extracellular cellulase production rates were considered as the factors that might contribute to difference in enzyme synthesis from different growth substrates. The analysis carried out in this work shows that the induction of cellulase in respect of enzyme formation rate $\left(Q_{p}\right)$, specific rate of enzyme production $\left(\mathrm{q}_{\mathrm{p}}\right)$ and enzyme/biomass yield $\left(\mathrm{Y}_{\mathrm{E} / \mathrm{X}}\right)$ was significantly higher when carboxymethyl cellulose (CMC) used as carbon source in the culture media. Moderate expression of all cellulolytic enzyme fractions were observed when Avicel and disaccharide like cellobiose or lactose was used as the carbon source. Glucose supported the maximum rate of cell mass formation $\left(Q_{x}\right)$, but repressed the cellulase synthesis in a dose dependent manner. It appeared that enzyme synthesis was controlled by two regulatory mechanisms: ( $i$ ) an induction mechanism (by $\mathrm{CMC}$ ) that enhanced the specific rate of enzyme production $\left(\mathrm{q}_{\mathrm{p}}\right)$ of CMCase, FPase and $\beta$-glucosidase up to 228.4, 26.6 and $35.2 \mathrm{U} / \mathrm{g}$ cell/h (highest yield), and (ii) a growth-dependent mechanism that changed the higher rate of synthesis $\left(\mathrm{Y}_{\mathrm{E} / \mathrm{X}}\right)$ in CMC-induced over non-CMC (other carbohydrates) induced cultures. Earlier studies suggest that separate regulation could exist for $\beta$-glucosidases, cellobiohydrolases, and endoglucanases (Ilmen, 1997). Our data show that the major cellulase fractions, CMCase, FPase and $\beta$-glucosidase of A.fumigatus ABK9, are coordinately expressed under all the conditions studied. These results indicate a common regulatory mechanism where CMC induces the proportionate expression of all cellulase fractions. This also justifies the selection of a most suitable soluble carbon source for cellulase production.

On the other hand, the supplementation of 2-deoxyD-glucose in the fermentation media clearly demonstrated that it had a profound effect on fungal growth and cellulases production. The profile of change in carbohydrate to protein ratio and residual sugar concentration indicates that due to relatively higher amount of enzyme production, the ratio decreased up to 1.13 in presence of 2-deoxy-D-glucose concentration of $0.5 \mathrm{mg} / \mathrm{ml}$. Above this concentration fungal growth was severely hampered, as a result both the amount of residual sugar and carbohydrate to protein ratio were increased. In the present study, 132.2, 21.3 and $28.9 \mathrm{U} / \mathrm{ml}$ of CMCase, FPase and $\beta$-glucosidase activity respectively was produced in the presence of $0.5 \mathrm{mg} / \mathrm{ml}$ of DG.

Thus the effect of 2-deoxy-D-glucose on cellulase production clearly demonstrated that it had a profound effect on increasing enzyme activity in the culture medium and also favored the transport of intracellular enzymes to extracellular medium, as was observed earlier (Mukherjee et al., 2006), though it hinders hyphal ghowth at increasing concentrations,
There is much evidence supporting the notion that cellulases are consecutive enzymes and their syntheses is induced by cellulose or small molecules released from cellulose (Messner and Kubicek, 1991; Kubicek, 1992). Since raw cellulose cannot directly enter into the fungal cell, it is generally believed that cellulose degradative products enter the cell, thus serving as the actual inducers to trigger high levels of cellulase gene expression (Seiboth et al., 1997). The soluble carbon source like CMC was easily utilized for the growth of A. fumigatus $\mathrm{ABK} 9$ and also acted as effective inducer for the production of cellulases. The induction ratio, defined as the ratio of inducer activity and basal activity, was 12.3-24.4 for cellulolytic enzymes in the presence of $1.5 \%$ (w/v) CMC. Higher concentration of CMC in the culture media suppressed cellulase formation and this can be attributed to the high viscosity of culture broth, which can interfere with the $\mathrm{O}_{2}$ transfer rate leading to the limitation of dissolved oxygen required for the growth of organism. Low level of cellulolytic enzymes in the presence of glucose in this study could be attributed to catabolic repression of synthesis of cellulolytic enzymes that was demonstrated in many organisms (Jorgensen et al., 2004).

Adequate supply of carbon, phosphate and nitrogen sources are the key factors affecting both productivity and fermentation time. The highest cellulase productivity was found in presence of $\mathrm{KH}_{2} \mathrm{PO}_{4}$ and yeast extract in the culture media of A. fumigatus ABK9. The C: $\mathrm{P}$ and $\mathrm{C}$ : $\mathrm{N}$ ratios of 4.0 and 10.0 were very much favourable for production of all cellulolytic enzymes. During the study on lignocellulose hydrolyzing capacity of the crude cellulases, highest rice straw saccharification efficiency of $46.3 \%$ was found at an enzyme load of $10 \mathrm{IU} / \mathrm{g}$ at $\mathrm{pH}$ 6. Varying saccharification efficiency at varied $\mathrm{pH}$ and enzyme concentration indicates that proper condition of their synergistic effect is very much essential for degradation of cellulosic fibers. The scanning electron microscopic view of the pre and post enzyme treated rice straw also supported the defragmentation of cellulosic fibers in the same conditions.

In summary, the results from this preliminary study showed that the newly isolated Aspergillus fumigatus ABK9 produced considerably higher level of extracellular cellulolytic enzymes, especially the activities of CMCase, FPase and $\beta$-glucosidase under submerged fermentation. The proportionate yields of these three different cellulolytic activities (cocktail mixture) are very essential for maximum saccharification of cellulosic materials into fermentable sugars. A kinetic study shows that cellulase production was growth associated. The biosynthesis of all cellulolytic enzymes by Aspergillus fumigatus ABK9 in the presence of single inducer (CMC) make this fungus worthy of further investigation. 


\section{Acknowledgements}

The authors are thankful to the University Grant Commission [Sanction No: F-3/2007 (BSR)/11-114/2008 (BSR)], Govt. of India for the financial contribution in this study.

\section{Literature}

Adsul M.G., J.E. Ghule, R. Singh, H. Shaikh, K.B. Bastawdea, D.V. Gokhale and A.J. Varma. 2004. Polysaccharides from bagasse: applications in cellulase and xylanase production. Carbohydr. Polym. 57: 67-72.

Agnihotri S.D. Dutt, C.H. Tyagi, A. Kumar and J.S. Upadhyaya. 2010. Production and biochemical characterization of a novel cellulase-poor alkali-thermo-tolerant xylanase from Coprinellus disseminatus SW-1 NTCC 1165. World J. Microbiol. Biotechnol. 26: 1349-1359.

Aguilar C.N., C. Augur and E.F. Torres. 2001. Induction and repression patterns of fungal tannase in solid-state and submerged cultures. Proce. Biochem. 36: 565-570.

Ahamed A and P. Vermette. 2009. Effect of culture medium composition on Trichoderma reesei's morphology and cellulase production. Biores. Technol. 100: 5979-5987.

Bartholomew, W.H., E.O., Karrow., M.R. Sfat and R.H. Wilhelm. 1950. Oxygen Transfer and Agitation in Submerged Fermentations. Effect of Air Flow and Agitation Rates upon Fermentation of penicillium chrysogenum and Streptomyces griseus. Ind. Eng. Chem. 42: 1801-1809.

Bergmeyer H.U. 1974. Methods of enzymatic analysis. Verlag Chemie, Weinheim, Berlin. $2^{\text {nd }}$ edn. 1025.

Bokhari S.A.I., F. Latif and M.I. Rajoka. 2008. Kinetics of highlevel of $\beta$-glucosidase production by a 2.-deoxyglucoseresistant mutant of Humicola lanuginosa in submerged fermentation. Braz. J. Microbiol. 39: 724-733.

Cybulska, I., H. Lei and J. Julson. 2010. Hydrothermal pretreatment and enzymatic hydrolysis of Prairie cord grass. Energy. Fuels. 24, 718-727.

Das, A and U. Ghosh. 2009. Solid state fermentation of waste cabbage by Penicillium notatum NCIM NO-923 for production and characterization of cellulases. J. Sci. Ind. Res. 68: 714-718.

Demain A.L., M. Newcomb and J.H.D. Wu. 2005. Cellulase, Clostridia, and Ethanol. Microbiology and Mol. Bio. Rev. 69: 124-154.

Elmer L. and Jr. Gaden. 2000. Fermentation Process Kinetics. Biotechnol. Bioeng. 67: 629-635.

Epps H.M.R. and E.F. Gale. 1942. The influence of the presence of glucose during growth on the enzymatic activities of Escherichia coli: comparison of the effect with that produced by fermentation acids. J. Biochem.36: 619-923.

Evsenko, M.S., A.S. Shashkov, A.V. Avtonomova, L.M. Krasnopolskaya, and A. I. Usov. 2009. Polysaccharides of basidiomycetes. Alkali-soluble polysaccharides from the mycelium of white rot fungus Ganoderma lucidum (Curt.: Fr.) P. Karst. Biochem. 74: 533-542.

Felsenstein J. 1985. Confidence limits on phylogenies: An approach using the bootstrap. Evolution 39: 783-791.

Gao J., H. Weng, D. Zhu, M. Yuan, F Guan and Yu. Xi. 2008. Production and characterization of cellulolytic enzymes from the thermo acidophilic fungal Aspergillus terreus M11 under solid state cultivation of corn stover. Biores. Technol. 99: 7623-7629.

Goodell B., J. Jellison, J. Liu, G. Daniel, A. Paszczynski, F. Fekete, S. Krishnamurthy, L. Jun and G. Xu. 1997. Low molecular weight chelators and phenolic compounds isolated from wood decay fungi and their role in the fungal biodegradation of wood. J. Biotechnol. 53: 133-162.
Haq, I., S. Khurshid, S. Ali, H. Ashraf, M.A. Qadeer and M.I. Rajoka. 2001. Mutation of Aspergillus niger for hyper production of citric acid following fermentation of blackstrap molasses. World J. Microbiol. Biotechnol. 17: 35-37.

Ibrahim M.M., W.K. El-Zawawy, Y.R.A. Fattah, N.A. Soliman, and F.A. Agblevor. 2011. Comparison of alkaline pulping with steam explosion for glucose production from rice straw. Carbohydr. Polym. 83: 720-726.

Ilmen M. 1997. Molecular mechanisms of glucose repression in the filamentous fungus Trichoderma reesei. VTT Publications 315: 1-86. Jeng W.Y., N.C. Wang, M.H. Lin, C.T. Lin, Y.C Liaw, W.J Chang, C. Liu, P.H. Liang and A.H.J. Wang. 2011. Structural and functional analysis of three b-glucosidases from bacterium Clostridium cellulovorans, fungus Trichoderma reesei and termite Neotermes koshunensis. J. Struct. Biol. 173: 46-56.

Jorgensen H., A. Morkeberg and K.B.R. Krogh. 2004. Growth and enzyme production by three Penicillium species on monosaccharides. J. Biotechnol. 109: 295-299.

Juhasz T., Z. Szengyel, K. Reczey, A.M. Siika and L. Viikari. 2005. Characterization of cellulases and hemicellulases produced by Trichoderma reesei on various carbon sources. Proc. Biochem. 40: 3519-3525.

Kubicek C.P. 1992. The cellulase protein of Trichoderma reesei: structure, multiplicity, mode of action and regulation of formation. Adv. Biochem. Eng. Biotechnol. 45: 1-27.

Kubicek C.P., R. Messner and F. Gruber. 1993. The Trichoderma reesei cellulase regulatory puzzle: from the interior life of a secretory fungus. Enzyme Microb.Technol.15: 90-99.

Laemmli U.K. 1970. Cleavage of structural proteins during the assembly of the head of bacteriophage T4. Nature. 227: 680-685.

Lawford, H and J.D. Rouseau. 1993. Manosse fermentation by ethanologenic recombinants of Escherchia coli. Biotechnol. Lett. 15: 615-620.

Lederberg J. 1992. Cellulases. In: Encyclopaedia of Microbiology 1; A-C, Academic Press, Inc.

Lockington, R.A., L. Rodbourn, S. Barnett, C.J. Carter and J.M. Kelly. 2002. Regulation by carbon and nitrogen sources of a family of cellulases in Aspergillus nidulans. Fungal Genetics and Biology 37, 190-196.

Lo C.M and L.K. Ju. 2009. Sophorolipids-induced cellulase production in cocultures of Hypocrea jecorina Rut C30 and Candida bombicola. Enzyme Microb. Technol. 44: 107-111.

Lowry O.H., N.J. Rosebrough, A.L. Farr and R.J. Randall. 1951. Protein measurement with the Folin phenol reagent. J. Biol. Chem. 193: 265-275.

Lynd L.R., P.J. Weimer and W.H. Van. 2002. Pretorius IS Microbial Cellulose Utilization: Fundamentals and Biotechnology. Microbiol. Mol. Biol. 66: 506-577.

Mach R.L. and S. Zeilinger. 2003. Regulation of gene expression in industrial fungi: Trichoderma. Appl. Microbiol. Biotechnol. 60: 515-522.

Magasani B.K. 1961. Catabolite repression. Cold Spring Harbor Symposia on Quantitative Biology 26: 249-256.

Mandels M., R. Andreotti and C. Roche. 1976. Measurement of saccharifying cellulase. Biotechnol. Bioeng. Symp. 6: 21-33.

Mandels M., F.W. Parrish and E.T. Reese. 1962. Sophorose as an inducer of cellulase in Trichoderma reesei. J. Bacteriol. 83: 400-408. Messner R. and C.P. Kubicek. 1991. Carbon source control of cellobiohydrolase I and II formation by Trichoderma reesei. Appl. Environ. Microbiol. 57: 630-635.

Miller G.L. 1959. Use of dinitrosalicylic acid reagent for determination of reducing sugar. Anal. Chem. 31: 426-428.

Muhannad I., W. Massadeh, W.M.W. Yusoff, O. Othman and K. Jalil. 2001. Synergism of cellulase enzymes in mixed culture solid substrate fermentation. Biotechnol. Lett. 23: 1771-1774. 
Mukherjee, S., S. Chowdhury, S. Ghorai, S. Pal, and S. Khowala. 2006. Cellobiase from Termitomyces clypeatus: Activity and secretion in presence of glycosylation inhibitors. Biotechnol. Lett. 28: 1773-1778. Pradnya D., N. Sajitha and K. Shubhangi. 2008. Water Hyacinth as Carbon Source for the Production of Cellulase by Trichoderma reesei. Appl. Biochem. Biotechnol. 158: 552-560.

Rajoka, M.I., A. Bashir, M.R.A. Hussain and K.A. Malik. 1998. Mutagenesis of Cellulomonas biazotea for improved production of cellulases. Folia Microbiol. 43: 15-22.

Rajoka M.I., M.W. Akhtar, A. Hanif and A.M. Khalid. 2006. Production and characterization of a highly active cellobiase from Aspergillus niger grown in solid state fermentation. World J. Microbiol. Biotechnol. 22: 991-998.

Rodrigues T.H.S., M.V.P. Rocha, G.R. Macedo and L.R.B. Gonçalves. 2011. Ethanol Production from Cashew Apple Bagasse: Improvement of Enzymatic Hydrolysis by Microwave-Assisted Alkali Pretreatment. Appl. Biochem. and Biotechnol. 164: 929-943. Saitou N. and M. Nei. 1987. The neighbor-joining method: A new method for reconstructing phylogenetic trees. Mol. Bio. Evolution. 4: 406-425.

Seiboth B., S. Hakola and R.L. Mach. 1997. Role of four major cellulases in triggering of cellulase gene expression by cellulose in Trichoderma reesei. J. Bacteriol. 179: 5318-5320.

Singhania R.R., R.K. Sukumaran, A.K. Patel, C. Larroche and A. Pandey. 2010. Advancement and comparative profiles in the production technologies using solid-state and submerged fermentation for microbial cellulases. Enzyme Microb. Technol. 46: 541-549.
Sterner R.W. and J.J. Elser. 2002. Ecological Stoichiometry: The Biology of Elements from Molecules to the Biosphere. Princeton University Press Princeton NJ, 584

Sun X., Z. Liu, K. Zheng, X. Song and Y. Qu. 2008. The composition of basal and induced cellulase systems in Penicillium decumbens under induction or repression conditions. Enzyme Microb. Technol. 42: 560-567.

Updegraff D.M. 1969. Semi micro determination of cellulose in biological materials. Anal. Biochem. 32: 420-424.

Vaheri M.P., M.E.O. Vaheri and V.S. Kauppinen. 1979. Formation and release of cellulolytic enzymes during growth of Trichoderma reesei on cellobiose and glycerol. European Journal of Appl. Microbiol. Biotechnol. 8: 73-80.

Vries R.P. and J. Visser. 2001. Aspergillus enzymes involved in degradation of plant cell all polysaccharide. Microbiol. Mol. Rev. 65: 497-522.

Wilson D.B. 2009 Cellulases and biofules. Curr. Opin. in Biotechnol. 20: $1-5$.

Wood T.M. and Bhat, K.M. 1988. Methods for measuring cellulase activity. In: Wood TM, Kellogg ST, editors. Methods in enzymology. London: Academic Press Inc. 160: 87-112.

Yue F.E.N.G., X.J. Jian and Z.H.U. Li-wei. 2009. Recent developments in activities, utilization and sources of cellulase. For Stud China 11: 202-207.

Zhang Y.P. and L.R. Lynd. 2005. Regulation of Cellulase Synthesis in Batch and Continuous Cultures of Clostridium thermocellum. J. Bacteriol. 87: 99-106. 